
Znanstvena revija, št. 3 / leto 2015 Univerza v Ljubljani

Fakulteta za arhitekturo in

Fakulteta za gradbeništvo in geodezijo

Ljubljana, 2015

Naslov revije:

\section{IGRA USTVARJALNOSTI}

teorija in praksa urejanja prostora

Urednici: Alenka Fikfak, Alma Zavodnik Lamovšek

Uredniki tematskega dela: Cristian Suau, Saja Kosanović, Carmelo Zappulla

Oblikovanje in naslovnica: Gašper Mrak Lektoriranje: Mojca Vilfan

Prevod: Mojca Vilfan

Klasifikacija: (UDK) Renata Stella Čop, (DOI) Teja Koler Povh

Založila in izdala: Univerza v Ljubljani, Fakulteta za arhitekturo in

Fakulteta za gradbeništvo in geodezijo

Spletna stran revije: http://www.iu-cg.org/

Spletna stran številke http://www.iu-cg.org/paper/2015/iu03.html

ISSN 2350-3637
Scientific journal, no. 3 / Year 2015

University of Ljubljana

Faculty of Architecture and

Faculty of Civil and Geodetic Engineering

Ljubljana, 2015

Title of the Journal:

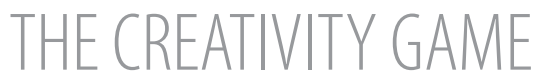

\section{Theory and Practice of Spatial Planning}

Editors: Alenka Fikfak, Alma Zavodnik Lamovšek

Thematic section editors: Cristian Suau,

Saja Kosanović, Carmelo Zappulla

Design and Title page: Gašper Mrak

Slovene text proofread by: Mojca Vilfan

Translation: Mojca Vilfan

Classification: (UDK) Renata Stella Čop, (DOI) Teja Koler Povh

Published by: University of Ljubljana,

Faculty of Architecture and

Faculty of Civil and Geodetic Engineering

Journal's Web Page:

http://www.iu-cg.org/

Currrent Issue LInk

http://www.iu-cg.org/paper/2015/cg03.html

ISSN 2350-3637
Univerza $v$ Ljubljani

Fakulteta za arbitekturo
Univerza $v$ Ljubljani

Fakulteta za gradbeništvo in geodezija

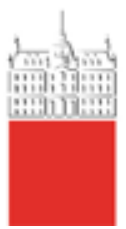




\section{JernejVidmar, Janez Koželj: PRILAGODLIVI URBANIZEM: pristop s parametričnimi kartami ADAPTIVE URBANISM: A Parametric Maps Approach}

\section{IZVLEČEK}

Velike okoljske spremembe in tehnološki razvoj, ki povzročajo hitre in nepredvidljive spremembe, silijo naša mesta v reorganizacijo in prilagoditev na vseh nivojih. Sodobna mesta postajajo vse bolj dinamična in odprta za prihodnje spremembe, katerim pa tradicionalni operativni instrumenti regulacije zazidave (npr. OPPN/zazidalni načrt) ne morejo slediti. Manjka jim prožnost in odzivnost, ki bi lahko sledili hitrosti in nepredvidljivosti sprememb. Zato potrebujemo bolj prilagodljive metode načrtovanja mest. $V$ tem članku predstavljamo novo metodo načrtovanja in oblikovanja, ki bi lahko izboljšala običajne instrumente regulacije zazidave. Predlagana metoda temelji na t. i. parametričnih kartah, ki omogočajo odprto, prožno in odzivno načrtovanje in oblikovanje mestne zazidave. Parametrične karte preoblikujejo regulacijska določila zazidave $v$ neposreden (interaktiven) prostor rešitev (ang. solution space), znotraj katerega je možno oblikovati in ovrednotiti množico veljavnih variant zazidave. To omogoča prilagodljivo načrtovanje mest, odprto za spremembe v prihodnosti. Da bi ocenili predlagano metodo, smo razvili interaktivno prototipno aplikacijo. Predhodni rezultati kažejo, da lahko z uporabo parametričnih kart, ki opisujejo regulacijske pogoje zazidave, izboljšamo proces urbanističnega načrtovanja in oblikovanja. Nakazujejo tudi, da bi parametrične karte lahko dopolnile običajne urbanistične dokumente na način, da ti postanejo bolj prožni in odzivni, kar bolje ustreza potrebam v načrtovanju in oblikovanju sodobnega mesta.

\section{KLUUČNE BESEDE}

prilagodljivo, parametrično, urbanistično načrtovanje, urbanistično oblikovanje.

\section{ABSTRACT}

Immense environmental changes and technological advancement, which are causing rapid and unexpected changes, are forcing our cities to reorganize and transform at all levels. As modern cities are becoming ever more dynamic and opened for future changes, the traditional operative instruments of development regulation (e.g. master plan) fall behind. They lack the flexibility and responsiveness needed to follow the speed and unpredictability of changes. Thus, more adaptive city planning methods are required. In this paper, we have presented a novel planning and design method that could enhance traditional instruments of development regulation. The proposed method is based on parametric maps, which enable open-ended, flexible and responsive planning of urban development. Parametric maps transform urban development regulations into direct (interactive) solution space within which a myriad of valid urban design alternatives can easily be created and evaluated. This enables adaptive city planning opened for future changes. To evaluate the proposed method, we have developed interactive prototype application. Preliminary results show that by using parametric maps to describe development regulations, urban planning and design process can be enhanced. They also indicate that parametric maps could complement conventional master plans to become more flexible and responsive, which better responds to the needs of planning contemporary cities.

\section{KEY-WORDS}

adaptive, flexible, parametric, urban planning, urban design. 


\section{INTRODUCTION}

Rapid technological advancement, which affects nearly all aspects of our lives, has been changing the way we live. It causes unforeseeable economic, social, and environmental changes that affect our cities, which are consequently being reorganized and transformed. Due to uncertainty and complexity of this process, cities »evolve in ways that are difficult to predict and ... city developments, even when planned, tend to find patterns of organisation that were not previously defined in the plans." (Beirão, 2012, p. 35). To make things worse, cities are also affected by high inertia. This is the result of long-term effects of spatial decisions, which are ultimately reflected in physical form. Once built, transport infrastructure and buildings stay there for a long time. The form of traditional master plans, which represent the final instrument of development regulation, has become too rigid and overdetermined to cope with the uncertainty and dynamics of the changes cities face. Schnabel \& Karakiewicz (2009, p. 94) state that it is »too precise, too prescriptive, ... not making allowance for changes.«. »Conventional urban scale master plans lack the flexibility required to account for ad-hoc changes and informal developments. They are static projections of a possible future." (Henn, 2014). Fixed master plans, which determine specific design in detail, thus hinder development of the city; they need to be frequently amended and updated using complicated, expensive and time-consuming procedures. To confront this intricate problem, we need to develop new kind of urban planning instruments, which will improve flexibility and responsiveness of development regulation (Šašek Divjak, 1999). We need adaptive urbanism, which will help cities stand up against erratic changes that come quickly and unexpectedly. As observed by Ho (2011, p. 5), we need master plans that will »maintain openness, allowing for creativity instead of limiting«.

\section{Although we have already accepted the fact that contemporary city} structure should be oriented towards unpredictable changes and continuous alternations, which take place quickly and unexpectedly (Čerpes et al., 2001), we have not yet been able to deal with this complex issue completely. One approach to mitigate effects of unpredictable future is to implement one of several alternative planning systems (e.g. performance-based planning or form-based codes), which emerged over the last half of the century (Goldstein, 2004; Hirt, 2007). These systems were developed to provide a framework that is more flexible and responsive than traditional zoning approach, yet with the same level of certainty (Steele \& Ruming, 2012). Nonetheless, it seems that the municipalities tend to avoid changing their planning systems due to many reasons (e.g. high migration costs, education of users or potential legal issues). If they decide to implement some form of the alternative planning systems, they tend to do so only partially by mixing it with the existing system (Elliott, 2008). Another way to address this problem is to unify technological capabilities and practice methods of urban planning and design (Pitts, Farley, \& Datta, 2013). For this, »we have to search for a new paradigm in the way of modelling urban form ... from fixed types and pre-determined shapes of elements of the model and to introduce a concept that will be generative as much as it is analytical« (Billen et al., 2014, p. 72).
This search has already begun in the past decade. Researchers around the world are striving to develop new (digitally-based) urban planning and design methods and techniques that enable more flexible and quicker response to unpredictable changes in space and time (Batty, 2013; Beirão, Duarte, \& Stouffs, 2011; DeVries, Tabak, \& Achten, 2005). Rather than designing a final solution (master plan), we should design its control system (Verebes, 2013a) and let the solution gradually evolve itself through time. According to several authors (Canuto \& Manuel, 2010; Steinø, 2010; Schumacher, 2013), parametric approaches seem to be the most suitable to fulfil this task. However, when exploring state-of-the-art case studies (e.g. Halatsch, Kunze, \& Schmitt, 2008; Verebes, 2013b; Aydin \& Schnabel, 2013), one can easily observe that with most parametric urban planning and design approaches - especially generative ones - users are expected to interact with computer by some form of programming techniques (e.g. scripts or visual programming). This may represent insurmountable problem, since most urban planners and designers are no programmers. Such approaches thus require a team of programmers (or at least designers with advanced computer literacy), which can only be afforded by the largest and/or enthusiast practices. In addition, open-ended master plans relying on programming techniques usually involve a lot of programming work to provide only one-time solutions. Thus, we should aim to develop more general and intuitive parametric planning and design methods.

In this article, we propose a novel operational urban planning and design method based on so-called parametric maps, which interactively regulate the form of development. They represent an instrument that directly connects separated boundary conditions of development to its form. We argue that by using the parametric maps method, we can establish interactive solution space within which numerous alternative urban designs can be created based on the same (fixed) development regulations. This, when implemented properly, can transform traditional static master plan to become open-ended system, which is more flexible and responsive for future changes. New method allows for: 1) quick and transparent creation of many equivalent design alternatives under the same development regulations and/or 2) quick adaptation of urban master plans according to changed conditions in (parts of) the city.

\section{THEORETICAL BACKGROUND}

To understand how the proposed method works, we first need to explain the difference and conflict between the two basic principles of contemporary urban planning and design practice. Local authorities (municipalities) traditionally set out the general urban plan on a top-down principle (Pissourios, 2014), which regulates city development using 2D maps and text documents. By defining a set of development regulations, they actually create boundary conditions that determine the solution space within which urban development can be designed. Each building of the development must comply with this set of constraints (development regulations) in order to ensure its coherence with the entire urban tissue. On the other side, urban designers take the bottom-up approach as they shape the actual (3D) urban space by placing, spacing and grouping buildings, one by one. Here they observe and evaluate spatial effects of the form and spaces between buildings they are creating. The design process is thus much closer to how 
cities actually evolve; as Batty $(2012$, p. S9) pointed out: „Cities ... evolve mainly from the bottom up as the products of millions of individual and group decisions with only occasional top down centralised action.«.

What we are dealing with here is a complex process that takes place between two (apparently opposite) sides: on one side there are many objective and measurable (quantitative) planning parameters and on the other side there are more specific and subjective (qualitative) design criteria. Although both sides seem different, they are inseparably connected. As is the case with urban planning and urban design, which are essentially the same (Gunder, 2011). Urban designers have to develop their spatial idea in compliance with all the requirements given in the land use plan, set of other spatial planning documents, laws, standards, and norms. These quantitative requirements set out the boundary conditions that define solution space within which the urban designers need to establish high quality relationships between multitude of buildings to form a whole development. Since there is much data involved, it is time-consuming and arduous task to harmonize both quantitative and qualitative aspects of urban design. Use of computer tools is thus inevitable.

Inability to effectively connect these two approaches results in rigidity of traditional master plans. We argue that by using parametric maps conventional master plan can be enhanced to become interactive instrument, which can better react to future needs and desires of the city. This is possible, as development regulations in general urban plan usually do not prescribe exact shape of development. They only set out the rules. If these rules are described properly (e.g. using parametric maps), they can be used to actually propel the creation process instead of limiting it.

In this article, we propose a new, semi-automatic performance-based parametric urban design method that fills the gap between top-down and bottom-up principles of urban planning and design. Using the new method, one can design urban development directly within the solution space, using both principles simultaneously. Working inside this solution space, a move from the design paradigm of 'form making' towards 'form finding' (Otto \& Rasch, 1996, cited in: Oxman, 2008) can be made. The proposed method is fully adapted to meet the specific requirements of two-dimensional urban planning and three-dimensional urban design at the same time. It is based on conventional regulation parameters (e.g. building's height or built-up area). Therefore, it can easily be integrated into the common urban planning and design workflow. Since the proposed method relies on instant visual and computationally intensive information feedback, it should be implemented as a computer application.

Before continuing, we also need to illuminate the difference between the conventional (metric) and the parametric design in the context of the proposed method. We see the parametric urban design as a method of modelling the development using the desired goal values, such as number of storeys or gross floor area of the building. This represents the main departure from traditional (CAD) methods, where each building is defined using traditional metric dimensioning, e.g. the building usually defined by the overall dimensions of $20 \times 20 \times 19 \mathrm{~m}$ can also be defined as an 8-sto-
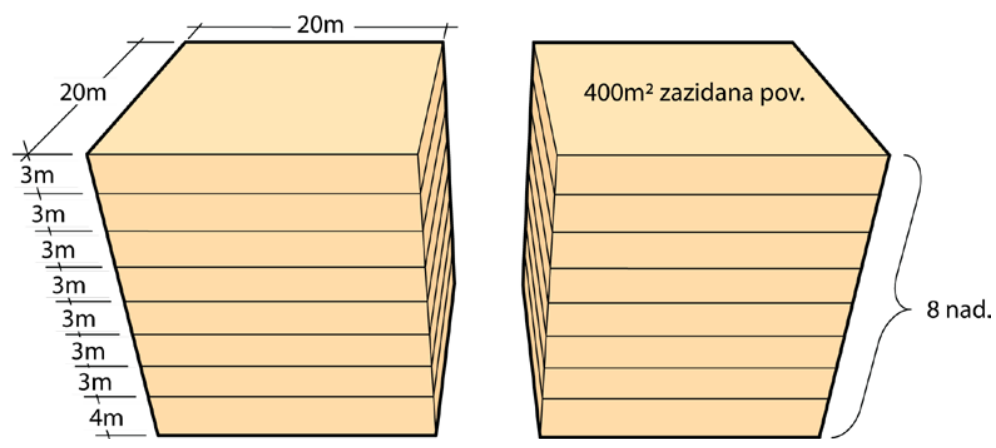

Figure 1: Metric and parametric dimensioning. Buildings are traditionally modelled using standard dimensioning (left), while parametric approach allows for more informative dimensioning using building's end values (right).

rey building with a $400 \mathrm{~m}^{2}$ built-up area (Figure 1). The advantage of this approach is obvious, since urban designers have more time to explore various possibilities directly within the desired end result, as they do not need to calculate building external dimensions in order to achieve desired end values.

\section{METHOD DEVELOPMENT}

\subsection{Parametric maps}

A parametric map represents spatial distribution of development parameters throughout the development area. It acts as a field of rules that regulate properties of development. The parametric map can be represented by ordinary (RGB or grey-scale) bitmap images projected (geolocated) onto the plot area, where each colour channel represents a selected parameter of the development, e.g. buildings heights or built-up areas. Since bitmap images themselves have fixed range of values (typically from 0 to 255), span of parameters values needs to be defined as well. Span of parameters is used to map fixed bitmap value to final parameter value. The building volume should then automatically be adapted based on final parameter values at specific location (Figure 2). To make parametric maps method interactive, it should be implemented as a computer application, which provides instant visual feedback by adjusting building volumes in real-time as they are moved around in virtual 3D environment. This way an open-ended operative control system of urban development regulation can be established.

Parametric maps establish a mechanism that acts on top-down principle, as they make sure that all newly placed buildings follow the regulations of the whole development area. They represent a solution space that adapts each building's volume in accordance with its location on site, thus creating a link between a set of rules and the actual shape of the development.

Once parametric maps are set-up, buildings (of arbitrary floor plan) can be inserted onto the plot area and adapted (in real-time) as they are moved around the area. This way the development can be designed based on the 


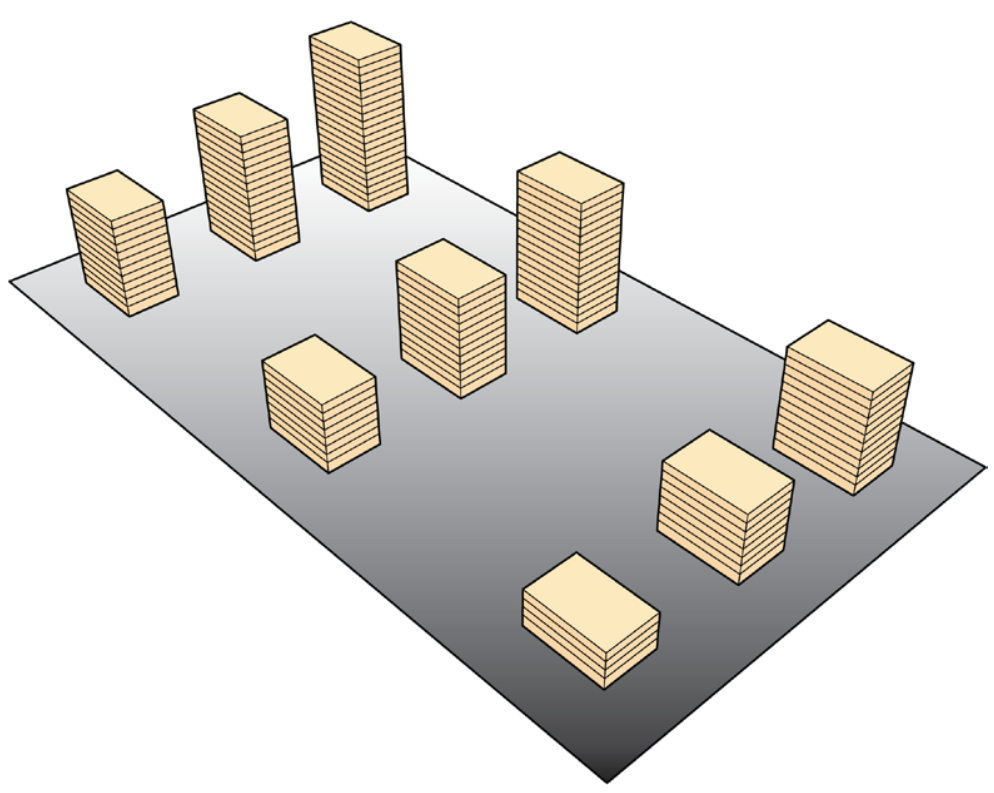

Figure 2: Example of parametric map for number of building storeys. Each building's height is adapted according to its location - white colour of parametric map represents tall buildings and black colour represents low buildings.

bottom-up principle without having to worry if the buildings comply with predefined development regulations - as they actually derive from them! This enhances the creative process and gives more time to check spatial effects of different design alternatives.

\subsection{Modus operandi - building heights calculation example}

Parametric maps are ordinary bitmap images projected onto the plot area, where the value of each colour channel represents selected parameter of the building at specific location. To keep things simple, we will explain how parametric maps work based on a single parameter - number of building storeys; other parameters, with the exception of land uses, also work in the same manner.

We start with the assumption that the data about the site in question has already been collected. Based on development goals, regulations and site survey, which are usually carried out in advance, one can already decide where the buildings should be high and where they should be low. Based on this decision parametric map that represents number of building storeys (BS) can be created, where black colour represents the lowest values (lowest number of building storeys in this case $-\mathrm{BS}_{\min }$ ) and white colour represents the highest values (highest number of building storeys in this case $-\mathrm{BS}_{\max }$ ), with grey shades in-between:

$\mathrm{BS}_{\min } \leq \mathrm{BS} \geq \mathrm{BS}_{\max }$

\section{Calculation example}

Because the value of building storeys parameter depends on its location on the development area, the building location (LBx,y) - vertical projection of building's centroid - needs to be remapped from absolute space to parametric map coordinate space (PMx,y). This ensures that the proper values are used accordingly to the building's location:

$\mathrm{LB}_{\mathrm{x}, \mathrm{y}} \rightarrow \mathrm{PM}_{\mathrm{x}, \mathrm{y}}$

Note that the building's centroid is used only for picking up the parameter value at certain location. In case when some of the building's exterior walls falls out of zoning area, the user should get an error notification.

The next step is to find out what is the 'raw' value of the parametric map (V) at specific location $\left(\mathrm{PM}_{\mathrm{x}, \mathrm{y}}\right)$. Using ordinary grayscale or RGB bitmap image, this is somewhere between $0\left(\mathrm{PM}_{\min }=\right.$ black) and $255\left(\mathrm{Pm}_{\max }=\right.$ white):

$\mathrm{PM}_{\text {min }}=0, \mathrm{PM}_{\text {max }}=255$
location $=\mathrm{PM}_{\mathrm{x}, \mathrm{y}}$
$0 \leq \mathrm{V}_{\text {location }} \geq 255$

The range limitation between 0 and 255 is the result of using standard 8-bit greyscale or 24-bit RGB colour model, which are the most widespread among computer applications. However, if higher accuracy is needed (e.g. when defining parameters that have more than 256 values), one could use a file format with a higher colour depth (e.g. 16-bit greyscale PNG format, which provides the range of values from 0 to 65,535$)$. However, this is not the case here. What is important is that these 'raw' values (from 0 to 255) need to be remapped to represent actual number of building storeys. For this, parameters span needs to be defined so that it reflects the lowest and the highest values of parameter. In our example, we have decided that the lowest buildings $\left(\mathrm{BS}_{\mathrm{min}}\right.$ ) should be 5 storeys high and that the highest buildings $\left(\mathrm{BS}_{\max }\right)$ should be 15 storeys high:

$$
\begin{aligned}
& \mathrm{BS}_{\text {min }}=5 \\
& \mathrm{BS}_{\text {max }}=15
\end{aligned}
$$

This way the parametric map is instructed to remap the $R$ value of 0 to 5 (storeys) and 255 to 15 (storeys). Any value between $0\left(R_{\min }\right)$ and $255\left(R_{\max }\right)$ is automatically recalculated using a simple linear interpolation:

$\mathrm{BS}=\mathrm{BS}_{\text {min }}+\left(\mathrm{BS}_{\max }-\mathrm{BS}_{\min }\right) * \mathrm{R}_{\mathrm{x}, \mathrm{y}} / \mathrm{R}_{\text {max }}$

Since we are calculating end values using linear interpolation, users can choose which colour (black or white) represents which value (high or low). An example to calculate number of building storeys at the location with an $R$ value of 215 follows:

$\mathrm{R}_{\mathrm{x}, \mathrm{y}}=215 ; \mathrm{BS}_{\text {min }}=5 ; \mathrm{BS}_{\text {max }}=15$

$\mathrm{BS}=5+(15-5) * 215 / 255=13.43$ 
The building at the location with $R$ value of 215 will thus be 13 floors high (13.43 needs to be rounded to integer). When moved around the virtual model, selected building should be instantly adapted to the required number of storeys according to recalculated $R$ value at given location. The same logic can also be applied to other parameters that define properties of buildings, such as built-up area or building orientation.

In addition to using parametric maps to regulate physical form of development, they can also be used to define non-physical properties, e.g. building's use based on parametric map of land uses. This is of special importance for proper calculation of urban control values as different land uses usually call for different requirements (e.g. requirement for calculation of parking lots for residential buildings differs from the one for office buildings). By using parametric maps of land uses an additional benefit of having a visual overview of building uses across the area is achieved, as each building instantly adapts its colour when moved onto another land use in virtual model. Since land uses are not numeric, they cannot be calculated using linear interpolation method described above. However, by employing direct RGB-to-land use mapping (specifying which RGB colour value corresponds to which land use) this problem becomes trivial.

\subsection{Classification of parameters and their relations}

In the previous section, we have explained the basic mechanism of parametric maps. However, not all parameters should be applied this way, as they regulate and control the development at different levels. Thus, we have defined different kinds of parameters (Table 1) to structure computer software algorithms and anticipated user workflow. We have separated regulation (input) parameters that are used to define the shape of development directly and control (output) parameters that are used to monitor the current state of development. In the context of input parameters, we have identified three sub-categories of parameters: 1) direct parameters, 2 ) indirect parameters, and 3) requirements. Each of these parameter categories has some specifics that determines their implementation. Control parameters are more straightforward, as they just need to be calculated in order to reflect the state of development. Nonetheless, we propose they are monitored at three levels: 1) for each building, 2) for each spatial unit, and 3) for the whole development.

Direct regulation parameters are used to regulate building volumes directly at their location in model. They are required to adapt each building directly as it is placed and moved around the virtual 3D model. An example of direct regulation parameters are number of building storeys, building's built-up area, etc. Direct regulation parameters are independent of indirect parameters and requirements, as they do not relate to any other parameter and/or calculation. However, they can be related interchangeably (one parameter can replace another) or interdependently (one parameter affects another parameter in the same sub-category).

Interchangeable parameters can be best illustrated by connection between building height and number of building storeys, where changing one will also change the value of another. They both have practically the same
Table 1: List of basic parameters. Parameters in italic are not implemented in prototype application. Please note that this list can be extended or reduced to fit the requirements of certain development/ municipality.

\begin{tabular}{|c|c|}
\hline \multicolumn{2}{|c|}{ REGULATION (INPUT) PARAMETERS } \\
\hline $\begin{array}{l}\text { DIRECT } \\
\text { PARAMETERS }\end{array}$ & $\begin{array}{l}\text { Building height } \\
\text { - } \text { Gumber of storeys } \\
\text { - } \text { Built-up area } \\
\text { - } \text { Othst storey height } \\
\text { - Ground floor hevel } \\
\text { - Number of basement floors } \\
\text { Building directions (orientation) } \\
\text { - Land use } \\
\text { Absolute min. distance between buildings }\end{array}$ \\
\hline $\begin{array}{l}\text { INDIRECT } \\
\text { PARAMETERS }\end{array}$ & $\begin{array}{l}\text { Allowed floor area ratio } \\
\text { Maximum lot coverage } \\
\text { Mean number of storeys } \\
\text { Relative min. distance between buildings } \\
\text { Min. distance from parcel boundary }\end{array}$ \\
\hline REQUIREMENTS & $\begin{array}{l}\text { Average size of apartment, office, etc. } \\
\text { Gross floor area per parking lot / } \\
\text { parking lot per appartment (office, etc.) / } \\
\text { parking lot per resident (workplace, etc.) } \\
\text { Required green area per apartment }\end{array}$ \\
\hline \multicolumn{2}{|c|}{ CONTROL (OUTPUT) PARAMETERS } \\
\hline $\begin{array}{l}\text { EACH BUILDING / } \\
\text { BUILDING PLOT }\end{array}$ & 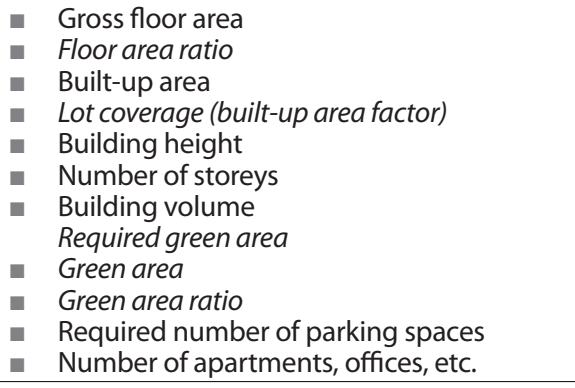 \\
\hline EACH SPATIAL UNIT & 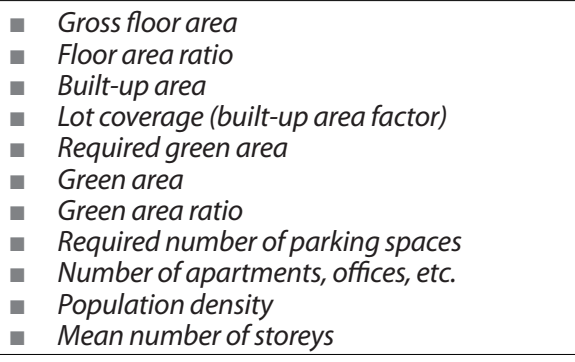 \\
\hline $\begin{array}{l}\text { WHOLE } \\
\text { DEVELOPMENT }\end{array}$ & 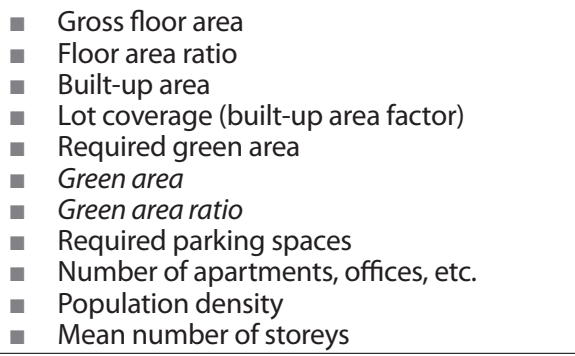 \\
\hline
\end{tabular}


impact on the building (presuming storeys height is defined). In fact, only one can be used, but for the sake of better user experience, we left both options open so that the user can use whichever he or she wants. Relations between interdependent parameters are a bit more complex, as there are several different ways they can be connected.

Interdependent parameters can be best described based on connection between number of building storeys, building's built-up area and gross floor area where one affects another. When e.g. number of building storeys is changed, it suffices to update only one of the two connected parameters - either gross floor area or built-up area. For the prototype, we have set the change of building's number of storeys to trigger update of gross floor area, while built-up area remains the same. Of course, it could be the other way round - when number of storeys is changed, built-up area is adapted to the size that keeps the gross floor area the same. In prototype application, we have already predefined these relations as described in results section (see prototype implementation). Nevertheless, user could also have the option to select different combinations based on own preferences.

Indirect regulation parameters are used to specify performance criteria (goal values) of the whole development area, spatial units and individual building plots. Examples of indirect parameters are allowable floor area ratio or minimum distance between buildings. Indirect parameters can typically be defined for the whole development area or separately for each urban block or subdivision of the development. Although these regulations are not used to define building's volumes directly, they need to be specified in advance as they determine constraints of the solution space. If the development's design comes into conflict with these pre-set regulations (e.g. floor area ratio becomes too high), urban designer needs to be warned about it immediately. Tool using this method should therefore automatically calculate urban control values and check if constraints are not being followed, thus enabling designers to work in line with regulation constraints at all times.

Requirements are parameters that are typically used to calculate the quantities and different kinds of facilities needed to support the development. Examples of requirements are average size of apartment (to assess how many apartments the development will provide) or required green area per apartment (to calculate how much green area is needed to support the development). Requirements are typically related to land uses, as each building use requires different values (e.g. number of required parking lots in residential buildings is different than in public buildings, even though they have same gross floor area). Since requirements do not define values that control physical appearance of development directly, they are closer to indirect than to direct parameters; they affect some of the control parameters that change as the development is being designed.

In addition to regulation parameters, which govern the physical form of the development, we have also classified control parameters that are used to monitor current state of the development as it is being designed. Control parameters represent the data that is needed to take well-informed decisions during the design phase. Real-time calculation and display of urban control values should thus be available at all times during the design phase. They can be calculated in two ways: 1) directly, based on physical state of development (e.g. floor area ratio) and 2) indirectly, based on requirements described above (e.g. required number of parking lots). To gain higher control over any and all parts of development, control parameters should be implemented for each building/building plot, for each spatial unit and as a sum for the whole plot.

\section{METHOD EVALUATION}

\subsection{Prototype implementation}

To test the proposed method, we have developed prototype application (Figure 3) in Maya ${ }^{2}$ (3D modelling and animation package by Autodesk), using its script language MEL. Basic usage is very simple: the user must first draw a floor plan or choose it from the library of predefined floor plans (e.g. square, circle, etc.). Once the floor plan is chosen, application generates building mass, including the floors. Once the building is generated, users can model the development in two ways. The first approach is to let every building automatically adapt its volume to the parameters defined by parametric maps in accordance with its location. When the building is then dragged around the area, application automatically adapts its volume in real-time based on the parameter values defined at its specific location.

The second way is to 'override' chosen building parameters, which allows for even greater flexibility of modelling the development. Once a selected building parameter is overloaded, it is not influenced by its parametric map any more. Using this kind of parameter overriding (user has to check parameter), it is important to note that one is consciously moving away from the outlined development as defined by regulation parameters. This approach can also be employed for quick visualisation of different alternatives prior to creating final parametric map.

Any change in the parameters, whether for the whole area or a single building, is reflected immediately. Set of urban control indicators, such as floor space area or number of required parking lots is calculated in realtime. We have implemented requirements, which are needed to calculate indirect control parameters, as a part of land use specification. This allows continuous supervision over the entire development and thus promotes performance-based urban design.

For the need of prototype implementation, we have pre-defined relations between interdependent parameters as described hereafter. We have chosen building height - which is the most dominant feature of the building - as our leading parameter, which should not change if not requested explicitly. From this, we have defined the following relations: 1) changing building's height (or number of storeys) adapts also its gross floor area, 2) changing building's built-up area adapts also its gross floor area, 3) changing building's gross floor area adapts also its built-up area and 4) chang-

1 A demonstration video of prototype application, which shows how parametric maps method works in real-time, is available at: http://tiny.cc/adaptive-urbanism. 2 http://www.autodesk.com/products/maya/overview 

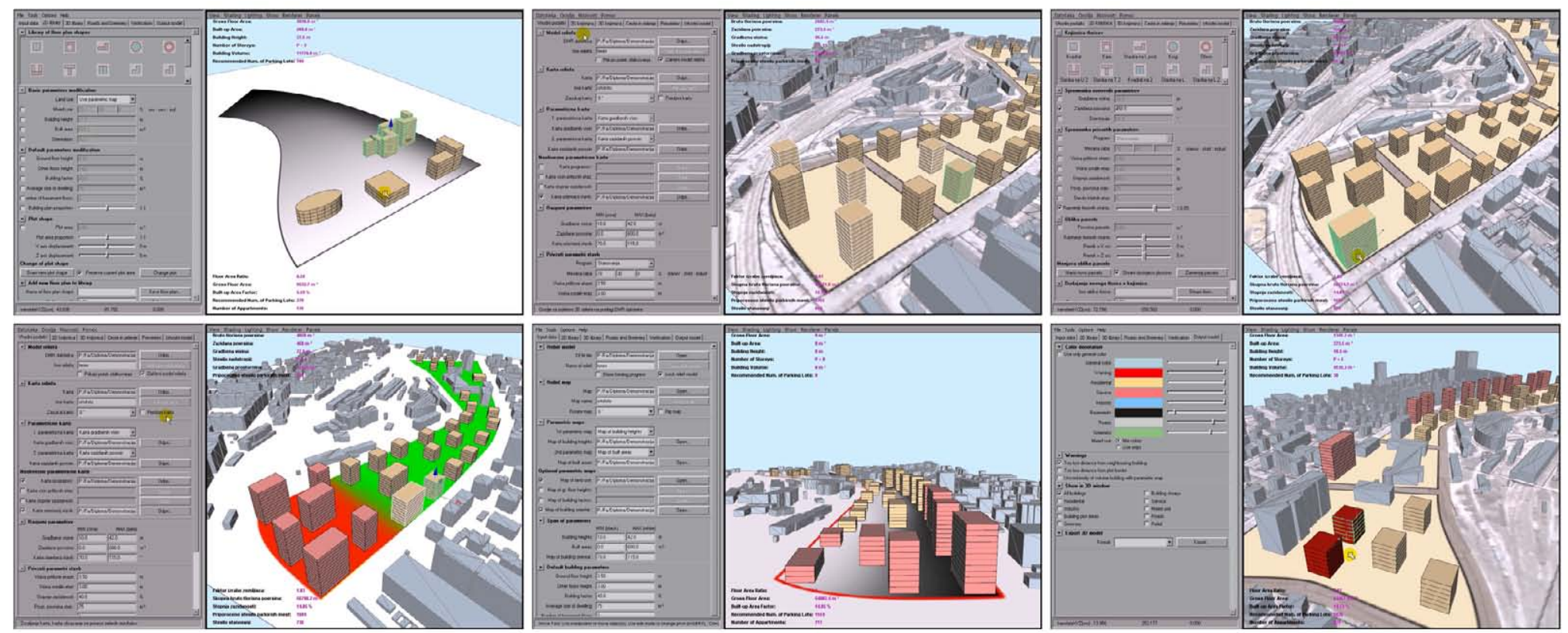

Figure 3: Screen-shots from the prototype application

ing building's storeys height adapts also its number of storeys so that it matches building height. It does not make sense to define parametric maps for parameters that exclude each other (e.g., when the storey height is constant, building heights and number of floors provide the same building property, only in a different way).

As an additional functionality, a prototype tool implements experimental function to raise error warnings when the spacing between the buildings is too small. This happens most often due to insufficient solar exposure of buildings or when the buildings are closer to each other than the minimum distance allowed.

\subsection{Preliminary results}

First internal tests of prototype application indicate that using parametric maps method together with real-time calculation of urban control values enhances urban design process. Increased speed and design flexibility allow for more time to verify alternative development proposals. The main contribution of parametric maps method is that it does not define development's end-state, but it rather sets out the interactive rules within which the development will evolve. Real-time calculation of urban control values can improve the quality of planned development, as one can take wellinformed decisions during the early stages of the design process. Authors also observed that the usefulness of parametric maps increases with the size of the development area, and vice versa. It seems that merging top-down and bottom-up approaches into a single design method not only facilitates the early stages of the design process, but it could also contribute to a more transparent and responsible urban planning and design in general.
When testing the prototype tool we have also observed out that design and verification of different development alternatives is facilitated as it enables rapid adaptation of buildings, all within the required criteria. This is an essential component of contemporary urban design practice, worthy of special attention. Since the individual buildings are interchangeable (Figure 4), the flexibility of the design, which complies with the planned development strategy, is increased and various alternatives can easily be tested. Parameters are not used to define the final solution, but rather a well performing solution space within which a designer has to find the best possible solution also in regard to qualitative terms (Turrin, Stouffs, \& Sariyildiz, 2013). This is not to say that anything goes, as working with parametric maps method still requires experts with solid urban design knowledge.

Prototype application showed that by using the proposed method, a shift from traditional design towards performance-based design has been made; this (in terms of urban planning and design practice) means that one can work with end-goal values and design the development at the same time. Real-time calculation of urban control values alone can be one of the most useful improvements to the existing practice, where the development is surveyed only once complete solution is designed. Using parametric maps in conjunction with requirements and real-time calculation of urban control values, several variables can be removed out of the design equation, which in turn makes it easier to solve.

We observed these main advantages when testing the prototype tool:

- rapid and transparent design of development alternatives;

- rapid and flexible response to new conditions;

- quick assessment of the development area capacity; 

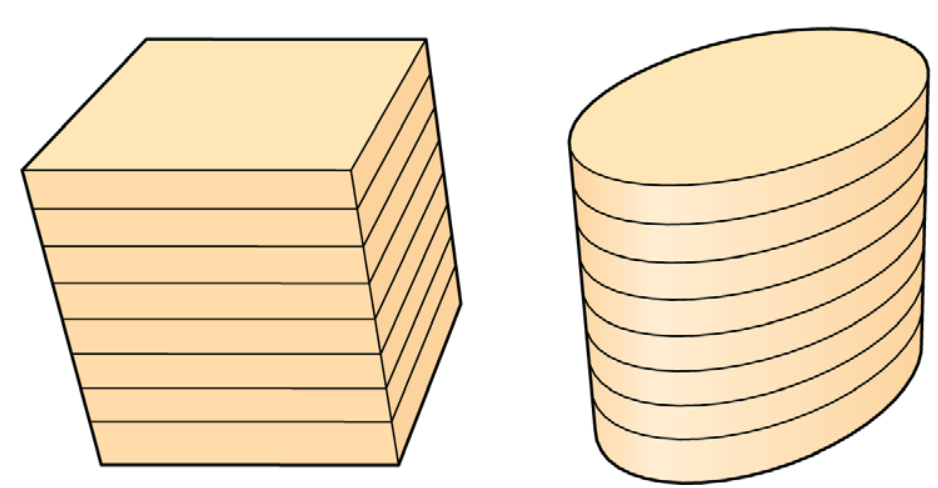

Figure 4: Interchangeability of buildings. Although of completely different shape, all three buildings in this example share the same height and gross floor area; thus one can easily replace another.

- well-informed decision making;

reduced probability of errors.

In addition to benefits, we also found out some shortcomings of the new method, as implemented in the prototype application:

- preparation of parametric maps can be time-consuming;

- errors in parametric maps or parameters span are hard to detect;

- lack of the tool for direct modelling of the buildings;

- redundancy of parametric maps when creating small scale developments.

\section{CONCLUSION}

New urban planning and design instruments should focus on coping with dynamics of city development. They should be able to steer diverse investment initiatives and development concepts in accordance with long-term spatial strategy of the city. In this article, we have presented an operational method that achieves this by connecting regulation and control parameters to the final form of the development. Prototype tool proved that parametric maps could establish interactive solution space, which enables creation of numerous alternative urban designs based on the same development regulations. This way the development can remain open for future changes until the time of actual implementation (e.g. getting construction permit). Parametric maps method, which represents operational bridge between urban control parameters and their spatial distribution, should thus be investigated further.

When compared to other emerging parametric urban planning and design tools, parametric maps approach has one big advantage - it provides a general framework that is simple and intuitive to use. This is a great advantage when compared to many other tools, which were, according to Pensa and Masala (2014), not yet adopted in practice mainly because they are technologically too advanced. Parametric maps represent straightforward and transparent way of specifying parameters values visually which can be easily understood by everyone.

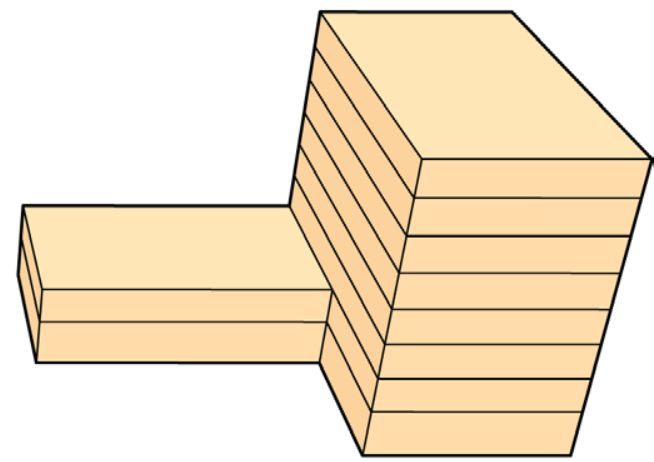

Current results imply the possibility of using parametric maps as a highly flexible and responsive instrument to regulate development. Proposed method can be used for both, the design of urban form as well as its regulation. Parametric maps could supplement (or maybe even replace?) fixed master plans and bring urban planning and design to a new level, which better responds to the needs of contemporary city. This will be the main focus of our further research, where we plan to organise several workshops to test the proposed method in practice.

As Lemmens pointed out "One of the most positive aspects of traditional zoning is its predictability." (2009, p. 127), but it comes at the cost of flexibility. Yet we have observed that predictability of end result is not sacrificed at the expense of flexibility when parametric maps method is used. However, there is one important issue that we have to solve in the future. Elliot (2008) noted that performance-based planning system (which we regard as the closest to the proposed method) was not widely adopted due to the people's desire for predictability. Not because the end-results are unpredictable, but rather as they can sometimes lead to too creative (unexpected) designs, which might not be accepted well by local community. Perhaps we can avoid these kinds of problems by engaging public in early phases of design, but we need to verify this assumption before making any claim.

We can use parametric maps to graphically describe quantifiable properties of the city. From this perspective, we can see them as a kind of city's genetic material, which defines numerous (mostly spatial) properties of the city. Number of parameters directly influences the size of solution space - the greater the number the smaller the number of possible solutions. If all parameters are defined (not all are described in this paper) one could actually use parametric maps to recreate virtual 3D models of existing cities. This raises interesting question about how many and which parameters should one define to achieve optimal regulation level? Which are the parameters that should be mandatory, which can be optional? This is an opened question we also need to deal with in the future. 


\section{ACKNOWLEDGEMENT}

\section{Authors would like to thank European Union (European Social Fund), which has part financed this research. We would also like to thank to PhD Martin Vuk and to the anonymous reviewer for the suggestions and comments that helped us improve the structure and clarity of this manuscript.}

\section{LITERATURA IN VIRI}

Aydin, S. (2013). CODING SHAPE GRAMMARS: Hints for generating a parametric design tool for large-scale urban renewal projects. In Cutting Edge: $47^{\text {th }}$ International Conference of the Architectural Science Association (pp. 177-186). Hong Kong: The Architectural Science Association (ANZAScA).

Batty, M. (2012). Building a science of cities. Cities, 29(6),S9-S16. http://dx.doi.org/10.1016/..ities.2011.11.008

Batty, M. (2013). The new science of cities. Cambridge, Massachusetts: The MIT Press.

Beirão, J. N. (2012). CltyMaker; Designing Grammars for Urban Design. A+BE |Architecture and the Built Environment (Vol. 2). Delft, Netherlands: TU Delft. http://dx.doi.org/10.7480/a+be.vol2.diss5.

Beirão, J. N., Duarte, J. P., \& Stouffs, R. (2011). Creating Specific Grammars with Generic Grammars: Towards Flexible Urban Design. Nexus Network Journal, 13(1), 73-111. http://dx.doi.org/10.1007/s00004-0110059-3.

Billen, R., Cutting-Decelle, A.-F., Marina, O., de Almeida, J.-P., Caglioni, M., Falquet, G.,"... Zlatanova, S. (2014). $3 D$ City Models and urban information: Current issues and perspectives. In R. Billen, A.-F. Cutting-Decelle, 0. Marina, J.-P. de Almeida, C. M., G. Falquet, ... S. Zlatanova (Eds.), 3D City Models and urban information: Current issues and perspectives - European COST Action TU0801 (pp. I-118). Les Ulis, France: EDP Sciences. http://dx.doi.org/10.1051/TU0801/201400001.

Canuto, R., \& Manuel, L. (2010). Parametric urbanism: emergence, limits and perspectives of a new trend in urban design based on parametric design systems. V!RUS, 3 .

Čerpes, I., Koželi, J., Blejec, G., Fatur, M., Gregorččč, G., Jankovičc, K., Matiašec, D., Simoneti, M., Struna, A. (2001). Priporočlla za urejanje naselij: zaključno poročllo o raziskovalni nalogi. Ljubljana, Slovenia: University of Ljubljana, Faculty of architecture.

DeVries, B., Tabak, V., \& Achten, H. (2005). Interactive urban design using integrated planning requirements control. Automation in Construction, 14(2), 207-213. http://dx.doi.org/16/j.autcon.2004.07.006.

Elliott, D. (2008). A better way to zone: ten principles to create more liveable cities. Washington, DC: Island Press.

Goldstein, J. (2004). Zoning Alternatives: Current Trends and New Directions. University of North Carolina. Accessed on 19.4.2014 at: https://cdrlib.unc.edu/indexablecontent/uuid:fdd51d84-a226-420a-abe0Od9d77849182.

Gunder, M. (2011). Commentary: Is Urban Design Still Urban Planning? An Exploration and Response. Journal of Planning Education and Research, 31 (2), 184-195. http://dx.doi.org/10.1177/0739456X10393358.

Halatsch, J., Kunze, A., \& Schmitt, G. (2008). Using Shape Grammars for Master Planning. In J. S. Gero \& A. K. Goel (Eds.), Design Computing and Cognition '08: Proceedings of the Third International Conference on Design Computing and Cognition (pp. 655-673). Springer Netherlands.

Henn (2014). Adaptive urbanism. Accessed on 20.6.2014: http://www.henn.com/en/research/adaptive-urbanism.
Hirt, S. (2007). The Devil Is in the Definitions. Journal of the American Planning Association, 73(4), 436-450. http://dx.doi.org/10.1080/01944360708978524.

Ho, J. K.-C. (2011). Cycle Study as the Basis of Adaptive Urbanism. In F. Neuhaus (Ed.), Studies in Temporal Urbanism (pp. 3-6). Dordrecht: Springer Netherlands. http://dx.doi.org/10.1007/978-94-007-0937-9.

Lemmens, M. (2009). Re-Zoning Alberta: Smart Regulation for Smart Growth. McGill International Journal of Sustainable Development Law and Policy, 5(1), 115-137.

Otto, F., \& Rasch, B. (1996). Finding Form: Towards an Architecture of the Minimal. Berlin, Germany: Edition Axel Menges.

Oxman, R. (2008). Performance-based design: current practices and research issues. International Journal of Architectural Computing, 06(01), 1-17. http://dx.doi.org/10.1260/147807708784640090.

Pensa, S., \& Masala, E. (2014). InViTo: An Interactive Visualisation Tool to Support Spatial Decision Processes. In N. N. Pinto, J. A. Tenedorio, A. P. Antunes, \& J. R. Clader (Eds.), Technologies for Urban and Spatial Planning: Virtual Cities and Territories (pp. 135-153). Hershey, PA: IGI Global. http://dx.doi.org/10.4018/978-14666-4349-9.ch007.

Pissourios, I. A. (2014). Top-down and bottom-up urban and regional planning: towards a framework for the use of planning standards. European Spatial Research and Policy, 21(1), 83-99. http://dx.doi.org/10.2478/ esrp-2014-0007.

Pitts, G., Farley, H., \& Datta, S. (2013). Research in practice: An exercise in generative urban massing. In R. Stouffs, P. Janssen, S. Roudarski, \& B. Tunçer (Eds.), Open Systems: Proceedings of the 18th International Conference on Computer-Aided Architectural Design Research in Asia (CAADRIA 2013) (pp. 685-694). Singapore: CAADRIA, CASA.

Schnabel, M. A., \& Karakiewicz, J. (2009). Rethinking Parameters in Urban Design. International Journal of Architectural Computing, 5(1), 84-98. http://dx.doi.org/10.1260/147807707780912994.

Schumacher, P. (2013). Free Market Urbanism - Urbanism beyond Planning. In T. Verebes (Ed.), Masterplanning the Adaptive City - Computational Urbanism in the Twenty-First Century. New York, ZDA: Routledge.
Steele, W., \& Ruming, K. J. (2012). Flexibility versus Certainty: Unsettling the Land-use Planning Shibboleth in Australia. Planning Practice and Research, 27(2), 155-176. http://dx.doi.org/10.1080/02697459.2012. 662670.

Steinø, N. (2010). Parametric Thinking in Urban Design: A Geometric Approach. In CAAD, Cities, Sustainability : Proceedings for the fifth International Conference of the Arab Society for Computer Aided Architectural Design ASCAAD 2010 (pp. 261-270). Fes, Morocco: ASCAAD.

Šašek Diviak, M. (1999). Guiding urban development on the municipal level. Urbani izziv, 10(2), 163-167. http://dx.doi.org/10.5379/urbani-izziv-1999-10-02-002.

Turrin, M., Stouffs, R., \& Sariyildiz, S. (2013). Performance-based parametrization strategies. In R. Stouffs, S. Janssen, \& B. T. Roudavski (Eds.), Open Systems: Proceedings of the 18th International Conference on Computer-Aided Architectural Design Research in Asia (CAADRIA 2013) (pp. 519-528). Singapore: CAADRIA, CASA.

Verebes, T. (2013a). Masterplanning the Adaptive City: presentation. Accessed on 11.9.2014: http://vimeo. com/74103602.

Verebes, T. (2013b). Masterplanning the Adaptive City: Computational Urbanism in the Twenty-First Century. (T. Verebes, Ed.). New York, ZDA: Routledge. 